\title{
'PACKHAM'S TRIUMPH' PEAR RESPONSE TO 1- METHYLCYCLOPROPENE AND NITRIC OXIDE TREATMENTS ${ }^{1}$
}

\author{
MARCOS VINÍCIUS HENDGES ${ }^{2 *}$, CRISTIANO ANDRÉ STEFFENS ${ }^{2}$, CASSANDRO VIDAL TALAMINI DO \\ AMARANTE $^{2}$, DANIEL ALEXANDRE NEUWALD ${ }^{3}$, AURI BRACKMANN $^{4}$
}

\begin{abstract}
This study aimed at assessing the effect of 1-methylcyclopropene (1-MCP), gas-nitric oxide (NO) and sodium nitroprusside (SNP) on ripening of 'Packham's Triumph' pears. The treatments consisted of $\mathrm{T}_{1}$ ) control; $\left.\left.\left.\mathrm{T}_{2}\right) 300 \mathrm{ppb} 1-\mathrm{MCP} ; \mathrm{T}_{3}\right) 1 \mathrm{mM} \mathrm{SNP} ; \mathrm{T}_{4}\right) 10 \mathrm{ppm} \mathrm{NO}$; and $\mathrm{T}_{5}$ ) $20 \mathrm{ppm}$ NO. The fruit treated with 1 MCP showed significantly higher values for flesh firmness, texture, and peel green color, besides lower respiratory rates and ethylene production. On the other hand, NO and SNP treatments did not reduce fruit respiratory rate and ethylene production. Flesh firmness and textural features were maintained by treating fruit with 20 ppm NO after leaving chambers. Treatments using $1 \mathrm{mM} \mathrm{SNP}$ and $20 \mathrm{ppm}$ NO kept peel green color (higher hue angle) when compared to control, without decreasing fruit yellowing during the shelf life. The application of $300 \mathrm{ppb} 1-\mathrm{MCP}$ prevented buttery texture and yellowing in 'Packham's Triumph' pear fruit during environment condition exposure. The use NO at $20 \mathrm{ppm}$ kept flesh firmness during storage, however, with subsequent reduction of this variable in environmental conditions. The treatments with $1 \mathrm{mM}$ SNP and 20 ppm NO maintained green peel of pear fruit, even after exposure to environmental conditions, but not limiting yellowing.
\end{abstract}

Keywords: Postharvest. Ripening inhibition. Pyrus communis L.

\section{RESPOSTA DE PERAS 'PACKHAMS TRIUMPH' AO TRATAMENTO COM 1- METILCICLOPROPENO E ÓXIDO NÍTRICO}

RESUMO - O objetivo deste trabalho foi avaliar o efeito do 1-metilciclopropeno (1-MCP), do óxido nítrico gasoso (NO) e do nitroprussiato de sódio (SNP) no amadurecimento de peras europeias 'Packhams Triumph'. Os tratamentos avaliados foram: $\mathrm{T}_{1}$ ) controle; $\left.\mathrm{T}_{2}\right) 300 \mathrm{ppb}$ de 1-MCP; $\mathrm{T}_{3}$ ) $1 \mathrm{mM}$ de SNP; $\left.\mathrm{T}_{4}\right) 10 \mathrm{ppm}$ de NO; e $\left.\mathrm{T}_{5}\right) 20 \mathrm{ppm}$ de NO. Frutos tratados com 1-MCP apresentaram valores significativamente maiores de firmeza de polpa, atributos de textura e cor verde da epiderme, além de menores taxas respiratória e de produção de etileno. Quanto aos frutos tratados com NO e SNP, não foi verificado redução da taxas respiratória e de produção de etileno. O tratamento com 20 ppm de NO manteve a firmeza de polpa e os atributos de textura na saída da câmara. Frutos tratados com $1 \mathrm{mM}$ de SNP e 20 ppm de NO apresentaram maior manutenção da cor verde da epiderme (maior ângulo hue) em relação ao controle, sem restringirem o amarelecimento dos frutos durante o período de prateleira. A aplicação de $300 \mathrm{ppb}$ de 1-MCP impediu o desenvolvimento de textura amanteigada e o amarelecimento de peras 'Packhams Triumph' durante o período de exposição dos frutos em condição ambiente. A utilização de 20 ppm de NO mantem a firmeza de polpa durante o armazenamento, com posterior redução em condição ambiente. A aplicação de $1 \mathrm{mM}$ de SNP e 20 ppm de NO mantem a epiderme dos frutos mais verdes, mesmo após o período de condição ambiente, porém não restringe o amarelecimento.

Palavras-chave: Pós-colheita. Inibição do amadurecimento. Pyrus communis L..

\footnotetext{
*Corresponding author

${ }^{1}$ Received for publication in 08/04/2014; accepted in 01/27/2016.

${ }^{2}$ Department of Agronomy, Universidade do Estado de Santa Catarina, Lages, SC, Brazil; marcos_hendges@hotmail.com, steffens@cav.udesc.br, amarante@cav.udesc.br.

${ }^{3}$ Competence Center for Fruit Growing - Lake Constance and Physiology of Specialty Crops, University of Hohenheim, Ravensburg, BW, Germany; neuwald@kob-bavendorf.de.

${ }^{4}$ Department of Plant Science, Universidade Federal de Santa Maria, Santa Maria, RS, Brazil; brackman@ccr.ufsm.br.
} 


\section{INTRODUCTION}

The 1-methylcyclopropene (1-MCP) is a molecule that acts by binding irreversibly to the ethylene-binding site, preventing it to link to its receptor (DE MARTINO et al., 2006). This molecule is effective in delaying ripening and reduction of certain physiological disorders in European pear (ARGENTA; FAN; MATTHEIS, 2003; CALVO; SOZZI, 2004; EKMAN et al., 2004). However, this product depends on factors such as concentration, harvest date and location, thus, being able to inhibit fruit ripening (CHIRIBOGA et al., 2013).

The best application methods of this product are still unknown, and nor is it clear which concentrations may be used without a total ripening inhibition of European pears (VILLALOBOS; MITCHAM, 2008). Therefore, it is important to search for new alternatives to its use.

Nitric oxide (NO) is an important signaling molecule that inhibit the ethylene production during ripening and storage (MANJUNATHA; LOKESH; NEELWARNE, 2010), being diffuse both in lipid and aqueous mediums which facilitates its multifunctional effect (SOZZI; TRINCHERO; FRASCHINA, 2003). Yet the sodium nitroprusside (SNP) is an effective NO donor agent (FLORYSZAK-WIECZOREK et al., 2006). The NO release mechanism through SNP is still not fully understood (WANG et al., 2002). Using NO and/or SNP consists of options that have good results in ripening delaying among a few fruits, such as European pear, strawberry, Asian pear and mango (LIU; DONG; GUAN, 2011; SOZZI;TRINCHERO; FRASCHINA, 2003; ZAHARAH; SINGH，2011; ZHU; ZHOU, 2007).

NO application delays ripening on European and Asian pears (LIU; DONG; GUAN, 2011; SOZZI; TRINCHERO; FRASCHINA, 2003), in addition to reducing the activity of enzymes that soften mango flesh (ZAHARAH; SINGH, 2011). SNP effectively inhibits the biosynthesis of autocatalytic ethylene in strawberries (ZHU; ZHOU, 2007) and slows ripening, increasing thus resistance pathogen attack besides stimulating the antioxidant activities in tomatoes (LAI et al., 2011). Fruit dipping into this product is a safe and practical alternative to NO application as the NO gas molecule is highly reactive to oxygen.

The objective of this study was to evaluate the effect of 1-MCP, NO gas and sodium nitroprusside (SNP) in the ripening process of European pears 'Packham's Triumph' cold stored.

\section{MATERIAL AND METHODS}

Harvested pear fruit of the 'Packham's Triumph' cultivar from commercial orchard located in São Joaquim-SC, Brazil, during the 2011-2012 crop seasons. The area is located at $28^{\circ} 17^{\prime} 36^{\prime \prime}$ South latitude and $49^{\circ} 56^{\prime} 1^{\prime \prime}$ West longitude. Of the fruits, we discarded those with defects and mechanical damages; we then proceeded sample homogenizing. The fruits underwent the following treatments: T1) control; T2) 300 ppb 1-MCP; T3), 1mM SNP; T4) 10 ppm NO; and T5) 20 ppm NO.

SmartFresh $^{\mathrm{TM}}$ was the commercial product used for 1-MCP treatment, being solubilized in water at ambient condition within a sealed container. Thereafter the solution was transferred to a petri dish, which was placed in airtight chamber together with the fruits and left exposed for 24 hours.

NO gas was also trapped into a sealed container and oxygen free for two hours. Total oxygen scanning was performed by nitrogen flow, after which NO gas was added to each respective dose. Fruit were immersed in SNP solutions with the respective concentration for twenty minutes. After application, fruit remained on workbench for solution draining and drying at ambient condition for two hours.

After treatment, the fruits were stored under refrigeration $\left(0 \pm 0.1^{\circ} \mathrm{C} / \mathrm{UR} 92 \pm 2 \%\right)$ for five months, followed by seven days at room conditions $\left(20 \pm 2^{\circ} \mathrm{C} /\right.$ UR $75 \pm 5 \%$ ). After being removed from the chamber, the fruits were left for seven days in room conditions; hence we evaluated flesh firmness, texture attributes (forces for peel disruption and flesh penetration) and peel coloration ('hue' angle $=h^{\circ}$ ). Concurrently, respiratory rate and ethylene production were also assessed.

Five fruit were placed in sealed for respiratory rate and ethylene production measurements. After one hour, we withdraw gas aliquots $(1 \mathrm{~mL})$, through a rubber septum. These aliquots were injected into a TC-3800 gas chromatograph (Varian, Palo Alto, CA, USA) equipped with a 3 -m-long Porapak N column (80$100 \mathrm{mesh})$, methanator and flame ionization detector for $\mathrm{CO}_{2}$ and ethylene concentration quantifying. The column, detector, methanator and injector temperatures were of $45,110,120$ and $300{ }^{\circ} \mathrm{C}$, respectively. Yet the nitrogen, hydrogen and synthetic airflows were of 30,70 and $300 \mathrm{~mL} \mathrm{~min}^{-1}$, respectively.

To measure flesh firmness, a portion of the fruit peel was removed and a 7.9-mm penetrometer tip was inserted into the fruit at two opposite regions within the larger fruit diameter portion. Texture attributes were performed with an electronic texture analyzer (Taxt-plus, Stable Micro Systems Ltd., London, UK). For penetration across peel and flesh, we used a PS2 tip, with $2 \mathrm{~mm}$ in diameter, which was introduced to a depth of $5 \mathrm{~mm}$ at a pre-test, test and post-test speeds of 30,5 and $30 \mathrm{~mm} \mathrm{~s}-1$, respectively. The color was evaluated by Minolta $\mathrm{CR}$ -400 colorimeter, wherein $h^{\circ}$ defines the basic color $\left(0^{\circ}=\right.$ red, $90^{\circ}=$ yellow, and $180^{\circ}=$ green $)$. Color 
was set by average of readings taken in opposite equatorial regions of the fruit.

The experimental design was completely randomized with four replications and each experimental unit composed of 20 fruit. The data underwent analysis of variance (ANOVA), and means compared by the Tukey's test $(p<0.05)$.

\section{RESULTS AND DISCUSSION}

The 1-MCP fruit showed lower respiratory rates and ethylene production, both just after being removed from chamber as after seven days under room condition. These outcomes corroborate Chiriboga et al. (2013) that reported fruit ripening reduction after 1-MCP treatment. Regarding the NO gas treated fruit, we observed increase in ethylene production during climacteric peak, and the dose of $20 \mathrm{ppm}$ remained highest production until the last day of evaluation, reaching substantial values to the sixth and seventh days. However, there was no increase in ethylene production with the application of the SNP compared to control (Figure 1). The respiratory rate was reduced in fruits treated with 1 $\mathrm{MCP}$, and from the sixth day the fruits treated with $10 \mathrm{ppm}$ NO also had lower rates than the control. On the seventh day, all treatments showed significant reduction in respiratory rate (Figure $1 \mathrm{~B}$ ).

A
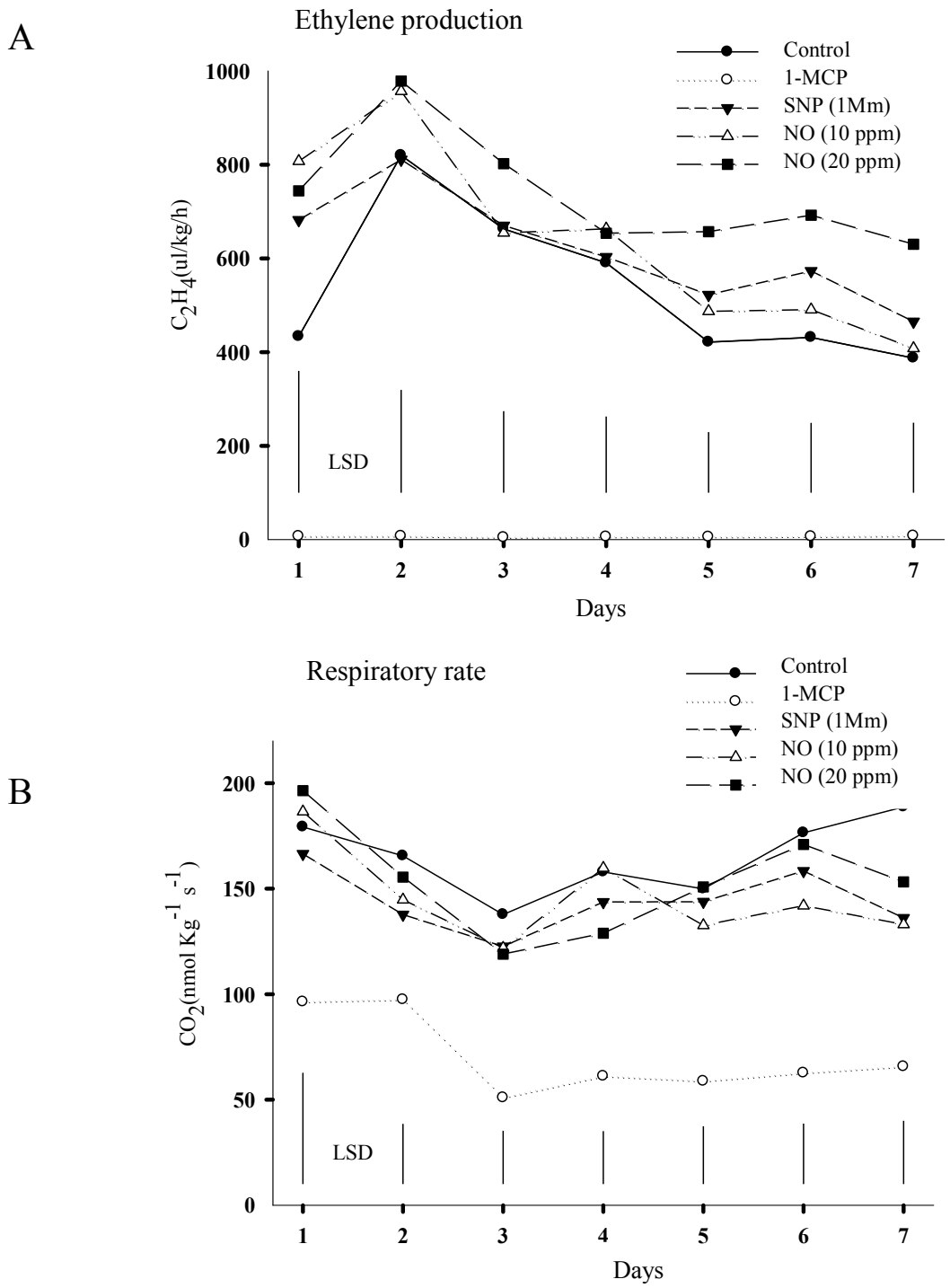

Figure 1. Ethylene production (A) and respiratory rate (B) of 'Packham's Triumph' pears subjected to 1-MCP (300 ppb), sodium nitroprusside $(1 \mathrm{mM})$ and nitric oxide gas $(10 \mathrm{ppm}$ and $20 \mathrm{ppm})$, being stored for 5 months $\left(0 \pm 0.1{ }^{\circ} \mathrm{C} / 94 \pm 2 \% \mathrm{RH}\right)$ plus seven days in room condition $\left(20 \pm 2^{\circ} \mathrm{C} / 60 \pm 5 \% \mathrm{RH}\right)$. LSD: least significant difference. Means were compared by the Tukey's test $(\mathrm{p}<0.05)$. 
According Manjunatha, Lokesh, Neelwarne (2010), NO inhibits ethylene production which occurs in maturation. According to these authors, one of the possible mechanisms of such inhibition is the binding of NO with 1-aminocyclopropane carboxylase oxidase (ACC oxidase), forming a binary compound of ACC oxidase-NO which is then chelated by ACC to produce a steady complex ACC - ACC oxidase - NO. This ternary complex, in turn, causes a decrease in ethylene production. Some studies have associated the effect of NO gas and SNP in reducing ethylene production to delayed fruit ripening (ZAHARAH; SINGH, 2011; ZHU; ZHOU,
2007). Nevertheless, this effect on ethylene production was not observed in this study. Sozzi, Trinchero and Fraschina (2003), studying 'Bartlett' pears, observed substantial increase in ethylene production in fruits treated with $50 \mathrm{ppm}$ NO for 12 hours, which was not found in fruits treated with 10 ppm, according to our results. These authors attributed such raise to possible stress caused by product concentration and/ or application duration. Shortly after storage removal, 1-MCP and $20 \mathrm{ppm}$ NO gas treatments provided greater flesh firmness comparing to the control, with higher values for 1MCP one (Figure 2).

A

Chamber withdrawal

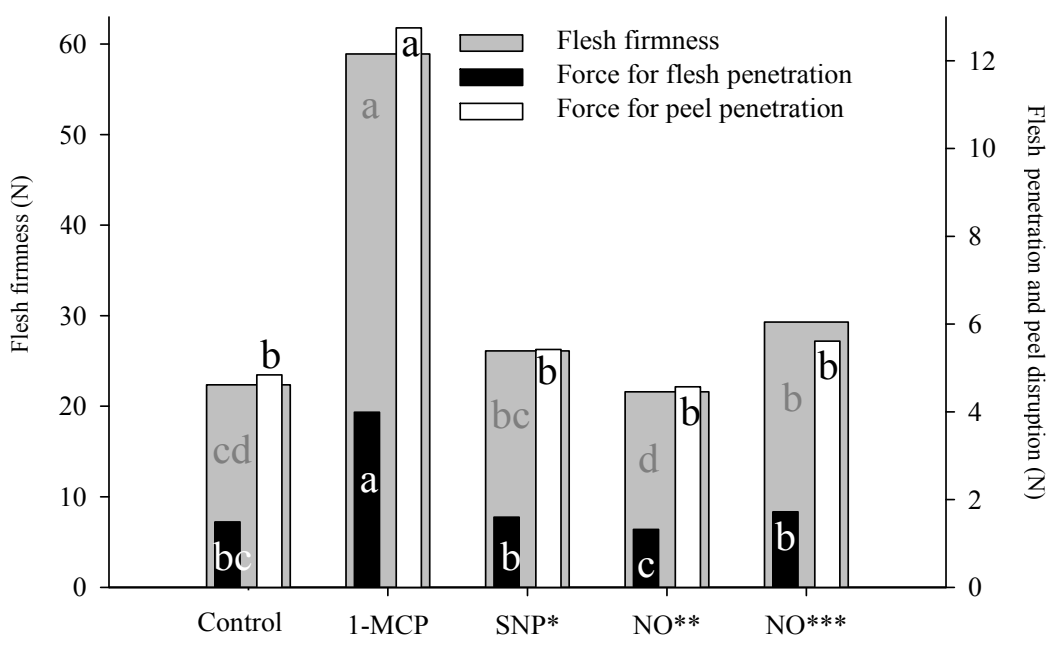

Room condition

B

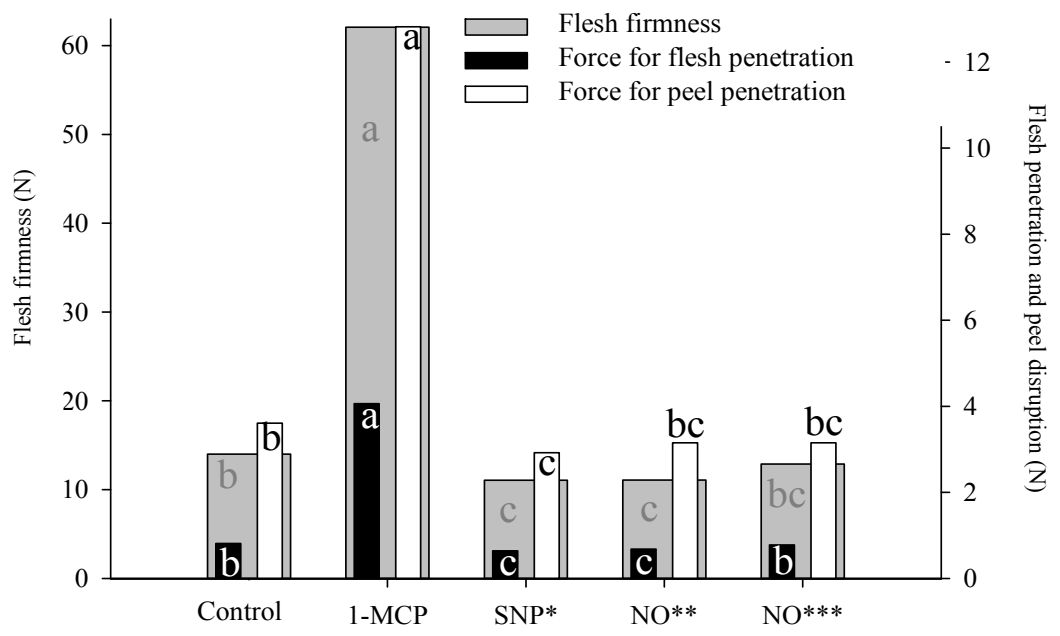

Figure 2. Flesh firmness and texture attributes of 'Packham's Triumph' pears submitted to 1-MCP (300 ppb), *sodium nitroprusside $(1 \mathrm{mM})$ and oxide nitric gas $(* * 10 \mathrm{ppm}$ and $* * * 20 \mathrm{ppm})$ stored for 5 months $\left(0 \pm 0.1{ }^{\circ} \mathrm{C} / 94 \pm 2 \% \mathrm{RH}\right)[\mathrm{A}]$, plus seven days under room conditions $\left(20 \pm 2{ }^{\circ} \mathrm{C} / 60 \pm 5 \% \mathrm{RH}\right)[\mathrm{B}]$. Means were compared by the Tukey's test $(\mathrm{p}<0.05)$. *Values followed by the same letter within the same column do not differ from each other. 
The effect of 1-MCP on flesh firmness of 'Rocha' and 'Conference' pears has been reported in several studies (CARVALHO, 2011; CHIRIBOGA et al., 2013). Moreover, Sun et al. (2011) found that the NO gas at 10 ppm could maintain flesh firmness and extend storage time of 'Feicheng' pear fruit. Zahara and Singh (2011) also found flesh firmness conservation for mangoes treated with 10,20 and 40 ppm NO gas. Liu and Dong Guan (2011) noted that Asian pear treated for 3 hours with 10, 20 and 30 ppm NO gas showed enhanced results for flesh firmness maintenance compared to untreated fruit. European pears has as ideal characteristic for consumption a buttery texture, featuring low firmness and juiciness; yet, it is desirable that fruits have a high flesh firmness at storage chamber removal, in order to facilitate handling during classification, processing, transport and marketing.

After seven days under room temperature, except for 1-MCP, all treatments did not inhibit flesh firmness reduction (Figure 2 B) and, consequently, showed buttery texture. Even after standing under ambient conditions, fruit treated with 1-MCP showed flesh firmness of approximately $60 \mathrm{~N}$. Chiriboga et al. (2013) also checked similar results. Conversely, buttery texture inhibition for European pears during the post-storage period is one aspect that compromises fruit quality. In addition, Ekman et al. (2004) did not noted buttery texture development in
European pear of 'Bartlett' cultivar after treating them with 1-MCP (1 ppm).

The 1-MCP fruit presented high-quality texture attributes in both evaluations (Figure 2). It is noteworthy that flesh firmness response to 1-MCP is directly related to ethylene action inhibiting. Fruit treated with both NO gas and SNP had no differences regarding forces required to penetrate peel and flesh at chamber withdrawal time.

Even though the NO gas at 20 ppm and SNP have had an effect on pear flesh firmness compared to control, we did not observe a response of the variable force for flesh penetration and peel rupture to these treatments (Figure 2). According Guillermin et al. (2006), there might be differences between fruit firmness measured with the aid of a penetrometer, and measures of force to penetrate flesh made through electronic texture analyzer. Therefore, we can infer that determining the flesh firmness with penetrometer disregards the resistance of epidermal tissue and hypodermic cell layer, which appear to protect the internal tissue against cell breakup.

Regarding the hue angle, both at chamber withdrawal and throughout seven days under room temperature, the fruits treated with $1-\mathrm{MCP}, 1 \mathrm{mM}$ SNP and $20 \mathrm{ppm}$ NO gas had higher values than the control, which evidences fruit with greener epidermal coloration (Figure 3).

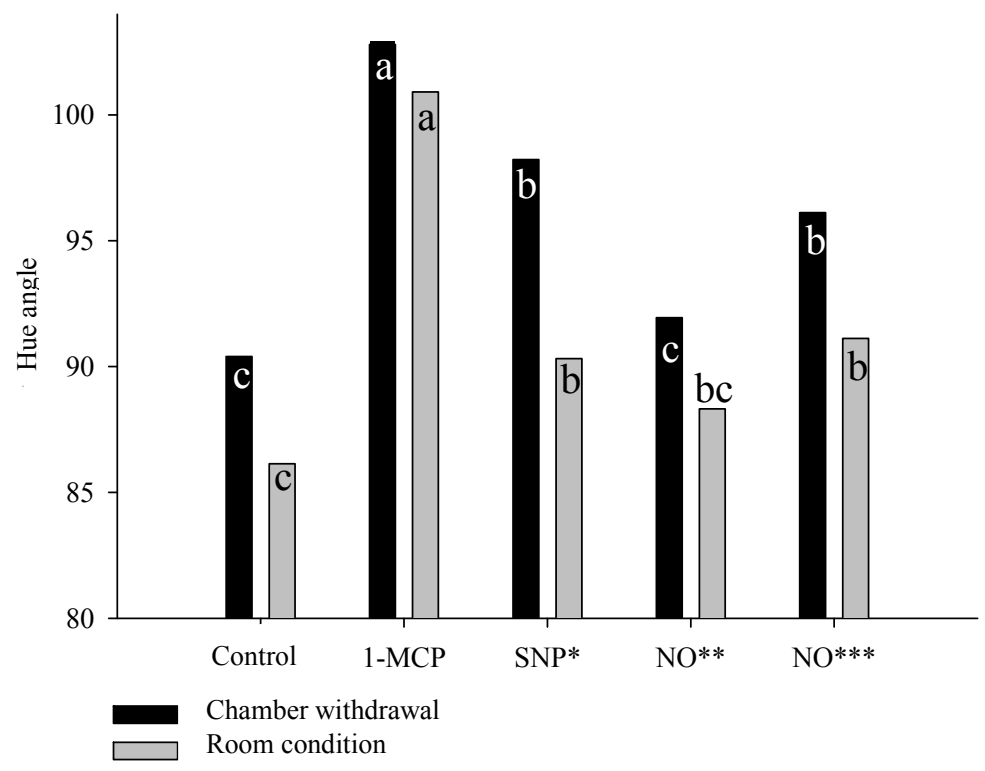

Figure 3. Green peel color (hue angle) of 'Packham's Triumph' pears submitted to 1-MCP (300 ppb), *sodium nitroprusside $(1 \mathrm{mM})$ and nitric oxide gas $(* * 10 \mathrm{ppm}$ and $* * 20 \mathrm{ppm})$, cold stored for 5 months $\left(0 \pm 0.1^{\circ} \mathrm{C} / 94 \pm 2 \% \mathrm{RH}\right)$, plus seven days in room condition $\left(20 \pm 2^{\circ} \mathrm{C} / 60 \pm 5 \% \mathrm{RH}\right) . *$ Values followed by the same letter within the same column do not differ from each other by the Tukey's test $(\mathrm{p}<0.05)$. 
Carvalho (2011) and Chiriboga et al. (2013) found epidermis yellowing delay in pears treated with 1-MCP. Regarding the effect of NO, Sozzi, Trinchero and Fraschina (2003) also observed a delay in fruit yellowing after being treated with 10 and $50 \mathrm{ppm}$ NO. The greenest fruit color for treatments of $20 \mathrm{ppm} \mathrm{NO}$ gas and $1 \mathrm{mM}$ SNP may come from the inhibition of chlorophyll degradation through the reduction of oxidative reactions. NO plays an important role reducing senescence related processes such as chlorophyll decomposition, chloroplast and thylakoid membrane degeneration (LIU; GUO, 2013). Eum, Wang and Lee (2009) reported that broccoli under $\mathrm{NO}$ gas treatment had malondialdehyde formation slow down, and thus lower lipid degradation, keeping the chlorophyll content. This was also found in fruits of kiwis, which treated with $20 \mathrm{ppm} \mathrm{NO}$ gas and $0.001 \mathrm{mM}$ SNP kept fruit with higher content of chlorophyll (ZHU; SUN; ZHOU, 2010). Furthermore, bananas treated with $5 \mathrm{mM}$ SNP had significant suppression in chlorophyll degradation (CHENG et al., 2009).

The lower ethylene production may have influenced the processes to change texture and color variables, since that helps trigger the two processes. According Agar et al. (2000), the ethylene concentration required for the softening of fruit is less than the amount to change fruit color from green to yellow in 'Bartlett' pears. In 'Forelle' pears, a similar behavior was observed by Toit et al. (2001), suggesting an ethylene content ceiling for the lowest softening of flesh tissue than to change the epidermal coloration.

\section{CONCLUSION}

In general, this study's results have shown that nitric oxide gas $(20 \mathrm{ppm})$ has effect on the ripening delay of 'Packham's Triumph' pears during storage period, but with less effectiveness compared to the 1MCP. Conversely, during shelf life, it has high ethylene production and therefore flesh softening, which is desirable during this period for pears.

Under conditions of this study, the application of $300 \mathrm{ppb}$ of 1-MCP has delayed the ripening of 'Packham's Triumph' pears and impaired the development of a buttery texture as well as fruit yellowing during shelf life.

The use of 20 ppm NO gas maintains flesh firmness and reduces color changes throughout storage with a subsequent reduction under room conditions.

Applying $1 \mathrm{mM} \mathrm{SNP}$ and $20 \mathrm{ppm}$ NO gas keeps fruit peel greener, even after exposure to environment condition, however, without restricting fruit yellowing as observed in fruit treated with 1MCP.

\section{ACKNOWLEDGEMENTS}

The authors want to thank the Conselho Nacional de Desenvolvimento Cientifico e Tecnológico - CNPq (National Council of Scientific and Technological Development) as well as the Fundação de Amparo à Pesquisa e Inovação do Estado de Santa Catarina - FAPESC (Foundation of Research and Innovation Support - FAPESC) by this research's financial support.

\section{REFERENCES}

AGAR, I. et al. Cold Storage Duration Influences Ethylene Biosynthesis and Ripening of Bartlettt'Pears'. HortScience, Amsterdam, v. 35, n. 4, p. 687-690, 2000.

ARGENTA, L.C.; FAN, X.; MATTHEIS, J.P. Influence of 1-methylcyclopropene on ripening, storage life, and volatile production by cv. d'Anjou pear fruit. Journal of Agricultural and Food Chemistry, Easton, v. 51, n. 13, p. 3858-3864, 2003.

CALVO, G.; SOZZI, G.O. Improvement of postharvest storage quality of 'Red Clapp's' pears by treatment with 1-methylcyclopropene at low temperature. Journal of Horticultural Science and Biotechnology, Dundee, v.79, n. 6, p. 930-934, 2004.

CARVALHO, A.R.S.C. Aplicação de SmartFresh $^{\text {TM }}$ em pêra 'Rocha': Eficácia de concentrações e modalidades de armazenamento na qualidade e na incidência de escaldão superficial e acastanhamento interno. 2011. 77f. Dissertação (Mestrado em Engenharia Agronômica) - Universidade Técnica de Lisboa, Lisboa, 2011.

CHENG, G. et al. Effect of nitric oxide on ethylene synthesis and softening of banana fruit slice during ripening. Journal of agricultural and food chemistry, Easton, v. 57, n. 13, p. 5799-5804, 2009.

CHIRIBOGA, M.A.et al. Responsiveness of 'Conference' pears to 1-methylcyclopropene: the role of harvest date, orchard location and year. Journal of Science Food and Agriculture, Malden, v. 93, n. 3, p. 619-25, 2013.

DE MARTINO, G.et al. 1-MCP controls ripening induced by impact injury on apricots by affecting SOD and POX activities. Postharvest Biology and Technology, Amsterdam, v. 39, n. 1, p. 38-47, 2006.

DU TOIT, P. G. et al. Exogenously applied ethylene reduces the cold requirement for ripening of pears (Pyruscommunis L.) cv. Forelle. South African Journal of Plant and Soil, Pretoria, v. 18, n. 4, p. 
$147-153,2001$.

EKMAN, J.H.et al. Interactions between 1-MCP concentration, treatment interval and storage time for 'Bartlettt' pears. Postharvest Biology and Technology, Amsterdam, v. 31, n. 2, p. 127-136, 2004.

EUM, H. L., WANG, D. K., LEE, S. K. Nitric oxide reduced chlorophyll degradation in broccoli (Brassica oleracea L. var. italica) florets during senescence. Food Science and Technology International,Washington, v. 15, n. 3, p. 223-228, 2009.

FLORYSZAK-WIECZOREK, J. et al. Do nitric oxide donors mimic endogenous NO-related response in plants?.Planta, Berlin, v. 224, n. 6, p. 1363-1372, 2006.

GUILLERMIN, P.et al. Rheological and technological properties of two cider apple cultivars. Food Science and Technology, Amsterdam, v. 39, n. 9, p. 995-1000, 2006.

LAI, T. et al. Defense responses of tomato fruit to exogenous nitric oxide during postharvest storage. Postharvest Biology and Technology, Amsterdam, v. 62 , n. 2, p. 127-132, 2011.

LIU, F.; GUO F-Q. Nitric Oxide Deficiency Accelerates Chlorophyll Breakdown and Stability Loss of Thylakoid Membranes during Dark-Induced Leaf Senescence in Arabidopsis. PLoS ONE, San Francisco, v. 8, n. 2, p. e56345, 2013.

LIU, L.; DONG, Y.; GUAN, J. Effects of Nitric Oxide on the Quality and Pectin Metabolism of 'Yali' Pears During Cold Storage. Agricultural Sciences in China, Beijing, v. 10, n. 7, p. 1125 1133, 2011.

MANJUNATHA, G.; LOKESH, V.; NEELWARNE, B. Nitric oxide in fruit ripening: Trends and opportunities. Biotechnology advances, Amsterdam, v. 28, n. 4 , p. 489-499, 2010.

SOZZI,G.O.; TRINCHERO, G.D.; FRASCHINA, A.A. Delayed ripening of 'Bartlettt'pears treated with nitric oxide. Journal of Horticultural Science\&Biotechnology, Ashford, v. 78, n. 6, p. 899903, 2003.

SUN, Z.; LI, Y.; ZHOU, J.; ZHU, S. Effects of exogenous nitric oxide on contents of soluble sugars and related enzyme activities in 'Feicheng' peach fruit. Journal of Science Food and Agriculture, Malden, v. 91, n. 10, p. 1795-1800, 2011.

VILLALOBOS, M.; MITCHAM, E.J. Ripening of
European pears: The chilling dilemma. Postharvest Biology and Technology, Amsterdam, v. 49, n. 2, p. 187-200, 2008.

ZAHARAH, S. S.; SINGH, Z. Postharvest nitric oxide fumigation alleviates chilling injury, delays fruit ripening and maintains quality in cold-stored 'Kensington Pride' mango. Postharvest Biology and Technology, Amsterdam, v. 60, n. 3, p. 202$210,2011$.

ZHU, S.; ZHOU, J. Effect of nitric oxide on ethylene production in strawberry fruit during storage. Food Chemistry, Amsterdam, v. 100, n. 4, p. 1517-1522, 2007.

ZHU, S.; SUN, L.; ZHOU, J. Effects of different nitric oxide application on quality of kiwifruit during $20^{\circ} \mathrm{C}$ storage. International Journal of Food Science \& Technology, Malden, v. 45, n. 2, p. 245251,2010 .

WANG, P. G.et al. Nitricoxide donors: chemical activities and biological applications. Chemical Reviews, Washington, v. 102, n. 4, p. 1091-1134, 2002. 